Acta Horticulturae et Regiotecturae 2

Nitra, Slovaca Universitas Agriculturae Nitriae, 2018, pp. 48-53

\title{
IMPACT OF ORGANIC FERTILIZERS ON MORPHOLOGICAL AND PHENOLOGICAL PROPERTIES AND YIELD OF TOMATOES
}

\author{
Magdaléna VALŠÍKOVÁ-FREY*, Dominika SOPKOVÁ, Marián REHUŠ, Patrik KOMÁR \\ Slovak University of Agriculture in Nitra, Slovak Republic
}

\begin{abstract}
The field trial was carried out in 2016 and 2017 on the grounds of the Botanical Garden of the Slovak University of Agriculture in Nitra. The aim of the paper was to test the impact of new organic fertilizers from Company Rokosan on the yield parameters and the morphological and phenological properties of tomatoes. In the experiments, we observed two determinant varieties, namely 'Brixol F1' and 'Uno Rosso F1'. We used the bulk organic fertilizer Rokosan P, designed for fruiting vegetables, and the liquid fertilizer Rokohumin Z. Both forms of fertilizers are produced as organic biomineral fertilizers, their main ingredient being keratin. They contain $9 \% \mathrm{~N}, 9 \% \mathrm{P}_{2} \mathrm{O}_{5}, 9 \% \mathrm{~K}_{2} \mathrm{O}, 3 \% \mathrm{MgO}$ and trace elements. The total harvest in the control variant without fertilization was the lowest compared to the fertilized variants. The second variant was fertilized with the Rokosan P fertilizer, and the harvests were in both years and in both varieties higher than in the variant 1 . The third variant was fertilized with the Rokohumin Z, the liquid fertilizer and achieved the best crop yields per plant. For the 'Uno Rosso F1' the best total harvest weight was $7.2 \mathrm{~kg}$ per plant in 2016 and 8.96 in 2017. For the 'Brixol F1', the highest harvest was $8.14 \mathrm{~kg}$ per plant in 2016 and $9.24 \mathrm{~kg}$ in 2017. In terms of yields and the number of fruits, combined fertilization with the bulk fertilizer Rokosan $\mathrm{P}$ and the liquid fertilizer Rokohumin $Z$ reached the second highest values.
\end{abstract}

Keywords: tomato, organic fertilizers

Solanum lycopersicum syn. Lycopersicon esculentum is originally a multi-year plant that is used in our growing conditions as a one-year crop. Tomato is growing worldwide in many climatic zones (Rubatzky and Yamaguchi, 1997; Heuvelink, 2005).

The largest producers of tomatoes in the world include China, India, USA, Turkey and Egypt. Annually, they produce tens of millions of tons (Faostat, 2014).

In Slovakia, tomatoes are grown on the total area of 700 hectares of arable land. This area produces about 19,000 tons of tomatoes. In addition, tomatoes are grown in home gardens and in protected areas. The annual consumption of tomatoes per capita represents almost $18 \mathrm{~kg}$, which approximately corresponds to the recommended dose (Meravá et al., 2017). Most tomatoes are grown in the Nitra, Trnava and Košice regions (Rozborilová et al., 2017).

Considering the demands of consumers to expand the range of organic vegetable products, we focused on growing tomatoes without the use of industrial fertilizers.

\section{Material and methods}

The field experiment was based on the grounds of the Botanical Garden of the Slovak University of Agriculture in Nitra (BG SUA in Nitra). We studied the impact of selected organic fertilizers on the yield and morphological and phenological properties of tomatoes. We observed two determinant varieties, namely 'Brixol $F 1$ ' and ,Uno Rosso F1.

Tomato seeds were sowed on March 14, 2016 and on March 13, 2017 in the heated greenhouse and seedlings were grown. One week before planting of seedlings in the field, the soil was fertilized according to the variants. Planting of seedlings took place on May 25, 2016 and May 23, 2017.

The crops were harvested, weighed separately according to the variants, repetitions and varieties. The first harvest was on August 8, 2016 and on August 7, 2017, about 75 days after the planting. The second harvest was on August 18, 2016 and on August 21, 2017. The third time we collected the yield on August 30, 2016 and on September 4, 2017.

Each variety was grown in four variants. Before the planting, the land was fertilized on May 20, 2016 and on May 16,2017 . During the vegetation, we fertilized twice on June 20, 2016 and on July 25, 2016. In 2017, we fertilized on June 15 and on July 24 .

The used fertilizers included humic acids. The dry, loose fertilizer Rokosan $\mathrm{P}$ is made on the basis of organominerals, the main component being keratin. It gradually releases nitrogen and meets the requirements for fruiting vegetables nutrition.

The second fertilizer was Rokohumin $Z$ in the liquid state. It also has a keratin base, made from organic waste. The fertilizer encourages growth start of seedlings after 
planting. It can also be used for hydroponics. This fertilizer contains macro elements and a wide range of micro elements (Rokosan, 2017).

\section{Data of field experiment}

Number of varieties: 2, Number of repeats: 3, Number of variants: 4 , Number of plants per variant: 18 , Spacing: $0.8 \times 0.6 \mathrm{~m}$.

\section{Used variants:}

1. Variant - control, without fertilization.

2. Variant - loose fertilizer (Rokosan P) containing humic acids. Fertilization

of $150 \mathrm{~g} \cdot \mathrm{m}^{2}$ before planting and at the same dose during vegetation after 25 days.

3. Variant - liquid fertilizer (Rokohumin Z) containing humic acids. Fertilization before planting at a dose of $15 \mathrm{ml}$ fertilizer per 1 liter of water. In the same amount during vegetation there was repeated fertilization after 25 days.

4. Variant - a combination of loose and liquid fertilizer containing humic acids. Fertilization at a dose $150 \mathrm{~g} . \mathrm{m}^{2}$ of bulk fertilizer and a liquid fertilizer at a dose $15 \mathrm{ml} .1^{-1}$ of water before planting. The combined fertilizations were repeated during vegetation 25 days after first application.

\section{Brief description of varieties}

'Uno Rosso F1' - medium-early determinant variety (102days vegetation period), suitable for mechanized harvesting. It grows strongly with high fertility. The fruits are slightly elongated, reaching the weight of 60-70 grams. By more frequent rainfall and irrigation they are resistant to cracking. The storage time is at least 20 days. It comes from Unigen Seeds - USA (Orosco, 2013).

'Brixol F1' - a determinant medium-early variety suitable for combine harvesting. It has a compact moderate growth. The fruits are elongated and resistant to cracking after frequent rainfall and irrigation. Thanks to the high content of lycopene, they are quickly coloured into a deep red color. The average fruit weight is $65-75 \mathrm{~g}$. The variety is very fertile if grown under irrigation and in warm areas. It comes from Unigen Seeds - USA (Orosco, 2013).

\section{Evaluation of the growing area}

The territory is set in a warm agroclimatic area. It is a dry sub-region with a mild winter and a longer sunshine. The Botanical Garden (BG) is located at the altitude of $130 \mathrm{~m}$. The average wind speed is $2.4 \mathrm{~m} . \mathrm{s}^{-1}$. The meteorological measurements were carried out at a meteorological station at the BG area in Nitra (Table 1).

\section{Soil conditions}

The land is located on an open plain. The land belongs to the category of heavy soil and clay species. The soil analysis to determine the nutrient content was done at the Department of Agrochemistry and Plant Nutrition before the experiment was established (Table 2).

\section{Used organic fertilizers}

Rokosan $\mathrm{P}$ is loose, intended for fertilization of fruiting vegetables. It is produced as an organic biomineral fertilizer and the main ingredient is keratin. It contains $9 \% \mathrm{~N}, 9 \%$ $\mathrm{P}_{2} \mathrm{O}_{5}, 9 \% \mathrm{~K}_{2} \mathrm{O}, 3 \% \mathrm{MgO}+$ trace elements. The content of the hazardous substances does not exceed the applicable limits according to the STN 654804 (Slovak Technical Standard). The fertilizer is a harmonious and balanced source of nutrients that are evenly released during the growing season. It supports the creation of flowers, increases fertility and biological activity of soil. It is recommended to be applied once before planting in the amount of 120-190 g.m ${ }^{-2}$ and the fertilized land shall be intensively irrigated. The fertilizer can be used before planting and during vegetation (Rokosan, 2017).

Rokohumin $\mathrm{Z}$ is a universally liquid fertilizer suitable for vegetables. The fertilizer is a unique one, considering its production of keratin basis from organic waste. The fertilizer is enriched with calcium, magnesium, iron and trace elements such as molybdenum, copper, boron, manganese, and zinc. The fertilizer is also suitable for hydroponic cultivation.

\section{Statistical evaluation}

The results were evaluated by Statgraphic Centurion XVII (StatPoint Inc. USA). An analysis of variance was performed and the mean values were tested by LSD at $95 \%$ significance.

Table 1 Average temperatures and rainfall during the growing season

\begin{tabular}{|l||c|c|c|c|c|}
\hline $\mathbf{2 0 1 6 / m o n t h}$ & May & June & July & August & September \\
\hline $\mathbf{T}\left({ }^{\circ} \mathbf{C}\right)$ & 15.0 & 20.3 & 21.4 & 19.5 & 17.5 \\
\hline $\mathbf{R}(\mathbf{m m})$ & 91.0 & 14.0 & 13.5 & 35.0 & 37.0 \\
\hline $\mathbf{2 0 1 7 / m o n t h}$ & May & June & July & August & September \\
\hline \hline $\mathbf{T}\left({ }^{\circ} \mathbf{C}\right)$ & 16.6 & 21.2 & 21.7 & 22.4 & 14.6 \\
\hline $\mathbf{R}(\mathbf{m m})$ & 14.0 & 26.1 & 60.0 & 23.2 & 93.0 \\
\hline
\end{tabular}

Table 2 Results of agrochemical analysis of soil

\begin{tabular}{|l||c|c|c|c|c|c|c|c|}
\hline \multirow{2}{*}{ Year } & Humus (\%) & \multirow{2}{*}{$\mathbf{p H} / \mathbf{K C l}$} & \multicolumn{6}{|c|}{ Nutrient content (mg.kg $\mathbf{- 1}^{\mathbf{1}}$ ) of soil } \\
\cline { 4 - 9 } & & & Nan & $\mathbf{P}$ & $\mathbf{K}$ & $\mathbf{S}$ & $\mathbf{C a}$ & $\mathbf{M g}$ \\
\hline \hline 2016 & $4.14 \mathrm{H}$ & $7.17 \mathrm{Ne}$ & $13 \mathrm{M}$ & $142.5 \mathrm{H}$ & $565 \mathrm{VH}$ & $16.3 \mathrm{~L}$ & $14,750 \mathrm{VH}$ & $740.9 \mathrm{VH}$ \\
\hline $\mathbf{2 0 1 7}$ & $3.75 \mathrm{G}$ & $7.18 \mathrm{Ne}$ & $10.1 \mathrm{M}$ & $147.5 \mathrm{H}$ & $477.5 \mathrm{VH}$ & $91.3 \mathrm{H}$ & $5,850 \mathrm{H}$ & $765.6 \mathrm{VH}$ \\
\hline
\end{tabular}

$\mathrm{H}$ - high content, $\mathrm{G}$ - good content, $\mathrm{pH}$ : Ne - neutral, $\mathrm{M}$ - medium content, L - low content, $\mathrm{VH}$ - very high 


\section{Results and discussion}

\section{Effect of fertilization on tomato yield}

In the first variant where the fertilizer was not used before planting and during vegetation, the results of the 'Brixol F1' variety were better. The 'Brixol F1' variety had a higher yield in all three collections. The total harvest of the 'Uno Rosso F1' in the control variant was $2.19 \mathrm{~kg}$ in 2016 and 3.79 $\mathrm{kg}$ per plant in 2017. For the 'Brixol F1' variety in the control variant, the yield was $3.19 \mathrm{~kg}$ in 2016 and $7.38 \mathrm{~kg}$ per plant in 2017. These harvests were lower than in other variants where different fertilization methods were used. Crop yields are generally related to the amount of nutrients received during vegetation (Hlušek, 2004).

The second variant was fertilized with bulk fertilizer and the harvest was higher in both years and at both varieties than in the control variant. The third variant was fertilized with Rokohumin $Z$, the liquid fertilizer and the best yields were achieved per plant. For the 'Uno Rosso F1' variety, three harvests consisted of the total fruit weight of 7.2 $\mathrm{kg}$ per plant in 2016 and 8.4 in 2017. The 'Brixol F1' had the highest yield in the

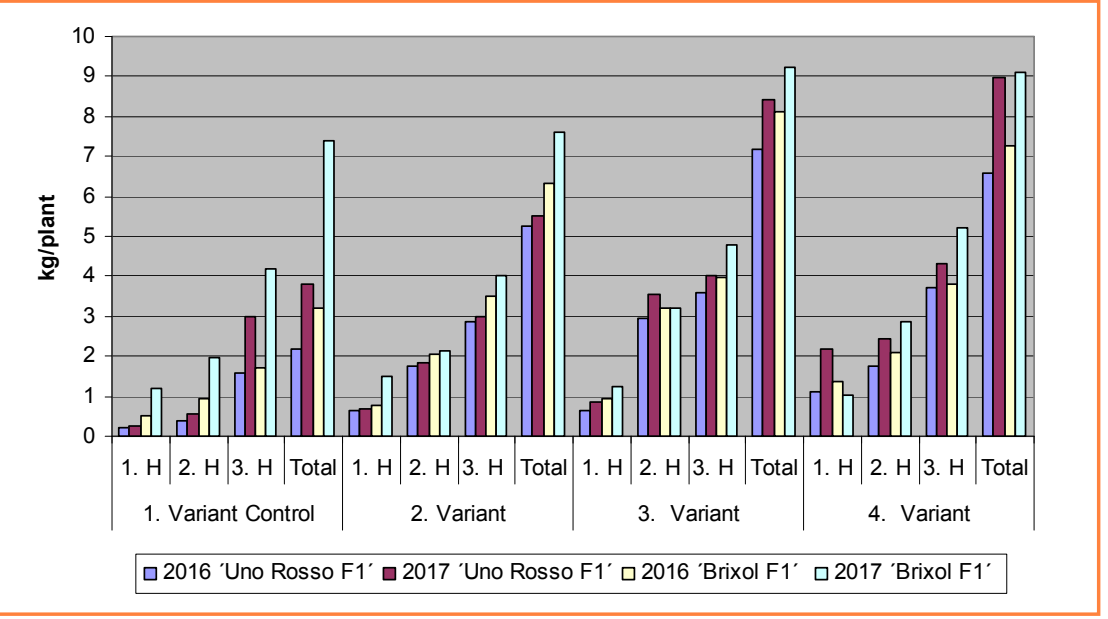

Figure 1 Yield of tomato in kg per plant

third variant, namely $8.14 \mathrm{~kg}$ per plant in 2016 and $9.24 \mathrm{~kg}$ in 2017.

The fourth variant in crop yields per kg of plant was mostly weaker than variant 3 , but still, the second best in the ranking (Table 3, Figure 1).

We found differences between variants in the number of fruits per plant. In 2016, there were harvested 34 pieces (control variant) to 111 pieces (third variant) from 'Uno Rosso $F 1$ ' variety. The 'Brixol F1' variety produced larger number of fruits in 2016, ranging from 46 to 116 pieces. In 2017, more fruits were found on plants than in 2016 (Figure 2).
Figure 3 shows that the year 2017 was generally more favourable for tomato crops than 2016. The reason was probably the weather with higher temperatures and rainfall in July, which is a period of intense fruit production.

The authors Patane and Cosentino (2010) noted that not only soil water deficiency, but also soil and climatic characteristics affect the tomato yield and quality. Helyes, Lugasi and Pek (2012) also identified the irrigation effect on the yield and the content of the antioxidant components of industrial tomatoes.

Table 3 Yield of tomato in kg per plant and number of fruits per plant

\begin{tabular}{|c|c|c|c|c|c|c|c|c|c|}
\hline \multirow[t]{3}{*}{ Variant } & \multirow[t]{3}{*}{ Harvest } & \multicolumn{4}{|c|}{ Variety 'Uno Rosso F1' } & \multicolumn{4}{|c|}{ Variety 'Brixol F1' } \\
\hline & & \multicolumn{2}{|c|}{ year 2016} & \multicolumn{2}{|c|}{ year 2017} & \multicolumn{2}{|c|}{ year 2016} & \multicolumn{2}{|c|}{ year 2017} \\
\hline & & $\mathrm{kg} / \mathrm{p}$ & $n / p$ & $\mathbf{k g} / \mathrm{p}$ & $n / p$ & $\mathbf{k g} / \mathrm{p}$ & $n / p$ & $\mathbf{k g} / \mathrm{p}$ & $n / p$ \\
\hline \multirow[t]{4}{*}{ 1. Variant (Control) } & first & 0.2 & & 0.25 & & 0.52 & & 1.2 & \\
\hline & second & 0.4 & & 0.54 & & 0.95 & & 1.98 & \\
\hline & third & 1.59 & & 3 & & 1.72 & & 4.2 & \\
\hline & together & 2.19 & 34 & 3.79 & 58 & 3.19 & 46 & 7.38 & 105 \\
\hline \multirow[t]{4}{*}{ 2. Variant } & first & 0.66 & & 0.70 & & 0.79 & & 1.5 & \\
\hline & second & 1.75 & & 1.85 & & 2.05 & & 2.12 & \\
\hline & third & 2.85 & & 2.98 & & 3.5 & & 4 & \\
\hline & together & 5.26 & 81 & 5.53 & 84 & 6.34 & 91 & 7.62 & 109 \\
\hline \multirow[t]{4}{*}{ 3. Variant } & first & 0.65 & & 0.85 & & 0.96 & & 1.24 & \\
\hline & second & 2.94 & & 3.55 & & 3.19 & & 3.2 & \\
\hline & third & 3.61 & & 4 & & 3.99 & & 4.8 & \\
\hline & together & 7.2 & 111 & 8.4 & 110 & 8.14 & 116 & 9.24 & 132 \\
\hline \multirow[t]{4}{*}{ 4. Variant } & first & 1.12 & & 2.19 & & 1.35 & & 1.02 & \\
\hline & second & 1.74 & & 2,45 & & 2.1 & & 2.88 & \\
\hline & third & 3.7 & & 4.32 & & 3.81 & & 5.2 & \\
\hline & together & 6.56 & 101 & 8.96 & 119 & 7.26 & 104 & 9.1 & 130 \\
\hline
\end{tabular}




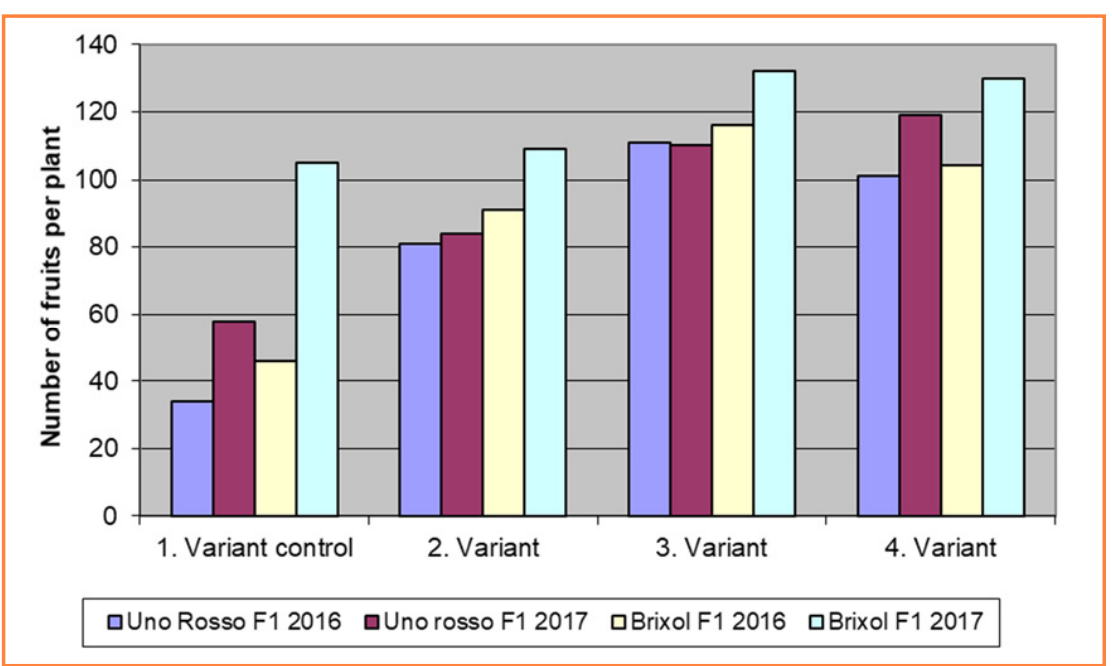

Figure 2 Number of fruits per plan $\mathrm{H}=$ harvest

Evaluation of the fertilizers' impact The yield and number of tomato fruits were highest in the variant with Rokohumin Z fertilizer. It is also evidenced by the highest total harvest in variant 3 in 2016. In 2017, the best harvests of 'Uno Rosso F1' were in the fourth variant and of 'Brixol F1' in $3^{\text {rd }}$ variant.

The liquid form of the fertilizer worked better than the powder. In general, organic fertilizers in combination with irrigations result in faster incorporation and decomposition of nutrients in the soil (Ložek et al., 2000).

In terms of yields and the number of fruit, the combined fertilization with bulk fertilizer Rokosan $\mathrm{P}$ and liquid fertilizer Rokohumin Z reached the second highest results.

The variant fertilized only with the bulk fertilizer Rokosan P placed third in the crop level. The reason may be the fact that loose organic fertilizers release nutrients more slowly than liquid or industrial fertilizers (Flowerdew, 2011).

Nevertheless, in the variety 'Uno Rosso $\mathrm{F}^{\prime}$ ' in 2016 , of $2^{\text {nd }}$ variant, the harvest was higher (5.26 kg per plant) than the unmanaged control variant (2.19 kg per plant). In 2017, the yield in the control variant reached $3.7 \mathrm{~kg}$ per plant and $5.53 \mathrm{~kg}$ per plant in the second variant. As for the 'Brixol F1' variety, the bulk fertilizer also increased the yield from $3.19 \mathrm{~kg}$ per plant (control) to $6.34 \mathrm{~kg}$ per plant.in 2016 and from 7.38 to $7.62 \mathrm{~kg}$ per plant in 2017.

According to the authors Taiwo, Adediran and Sonubi (2008), organic fertilizers are important sources of plant nutrition and can be alternatives to synthetic fertilizers. Even a recent research (Wang and Xing, 2017) confirmed the positive effects of irrigation and fertilization on tomato fruit yield and quality.

\section{Impact assessment of years}

There were marked differences between the yields in individual years of the experiment in favour of 2017 in both varieties. In the 'Uno Rosso F1' variety, crop yields in 2016 ranged from 2.19 to $7.2 \mathrm{~kg}$ per plant and in 2017 from 3.79 to $8.96 \mathrm{~kg}$ per plant. The 'Brixol F1' variety also showed higher yield in 2017. The yield ranged from 3.19 to $7.26 \mathrm{~kg}$ per plant in 2016 and from 7.38 to $9.24 \mathrm{~kg}$ per plant in 2017.

\section{Impact assessment of varieties}

The 'Brixol F1' variety was more fertile in both years and in all variants. Even when evaluating the number of fruits per plant, the 'Brixol F1' was more successful in both years. These differences can be seen in Table 3 . Tigist, Workneh and Woldetsadik (2012) confirmed the variability of the properties of different varieties of tomatoes when their research focused

Table 4 Multiple Range Tests for Yield kg / plant by varieties, years, variant and harvest

\begin{tabular}{|c|c|c|c|c|c|c|}
\hline Varieties & Count & LS Mean & LS Sigma & \multicolumn{3}{|c|}{ Homogeneous Groups } \\
\hline Uno Rosso & 24 & 1.99542 & 0.103177 & $x$ & & \\
\hline Brixol & 24 & 2.42792 & 0.103177 & & $x$ & \\
\hline Years & Count & LS Mean & LS Sigma & \multicolumn{3}{|c|}{ Homogeneous Groups } \\
\hline 2016 & 24 & 1.9225 & 0.103177 & $x$ & & \\
\hline 2017 & 24 & 2.50083 & 0.103177 & & $x$ & \\
\hline Variants & Count & LS Mean & LS Sigma & \multicolumn{3}{|c|}{ Homogeneous Groups } \\
\hline 1. V & 12 & 1.37917 & 0.145914 & $X$ & & \\
\hline 2. V & 12 & 2.0625 & 0.145914 & & $x$ & \\
\hline 4. V & 12 & 2.65667 & 0.145914 & & & $x$ \\
\hline 3. V & 12 & 2.74833 & 0.145914 & & & $x$ \\
\hline Harvest & Count & LS Mean & LS Sigma & \multicolumn{3}{|c|}{ Homogeneous Groups } \\
\hline First & 16 & 0.95 & 0.126365 & $X$ & & \\
\hline second & 16 & 2.10562 & 0.126365 & & $x$ & \\
\hline Third & 16 & 3.57938 & 0.126365 & & & $x$ \\
\hline
\end{tabular}

Method: $95.0 \%$ LSD 


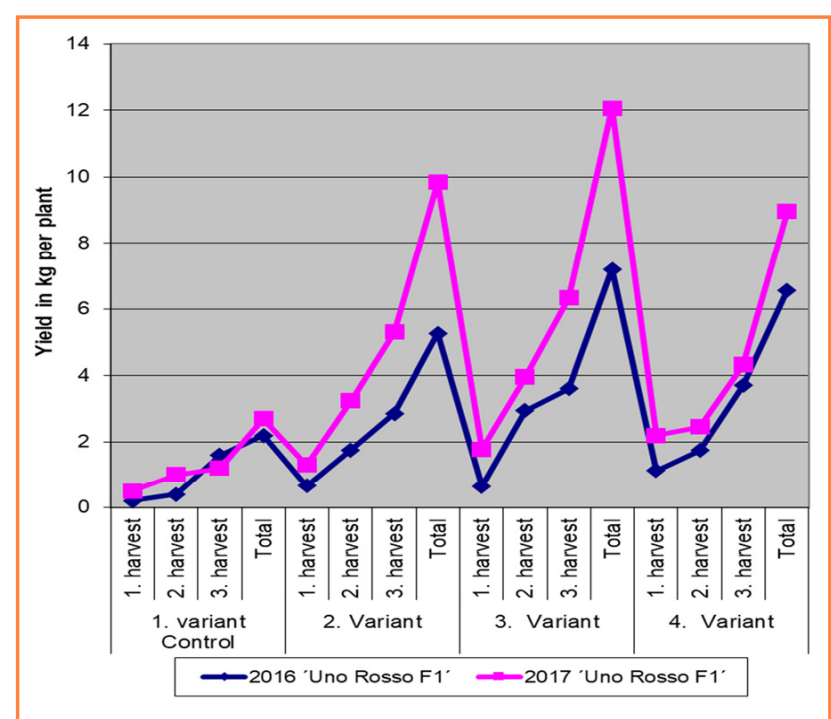

Figure 3 Comparison of 'Uno Rosso F1' variety yield in 2016 and 2017

on the influence of varieties on the crop, the physical and storage properties of tomatoes.

\section{Results of statistical evaluation}

The tests for crops in kg per plant and fruit numbers per plant showed significant differences between varieties, years, variants and collection dates (Table 4 and 5).

\section{Evaluation of morphological and phenological properties}

Selected morphological and phenological properties were evaluated according to the international tomato descriptor (IPGRI, 1996). This evaluation system is used by researchers, gene resources investigators and breeders. The morphological features of tomatoes should not change significantly over the years and, therefore, we only evaluated these indicators in 2016. Differences in the observed properties were found among varieties but not among variants. This means that the use of different fertilizers did not have any significant effects on the morphology and phenology of tomatoes.

\section{Morphological properties}

\section{Plant and leaf}

Both varieties are of determinate type, suitable for field cultivation with the possibility of mechanized harvesting (Uher et al., 2016). The variety of 'Uno Rosso F1' ranged up to the height of $0.3 \mathrm{~m}$ and the variety of 'Brixol F1' reached the height of $0.5 \mathrm{~m}$. The stronger stem was found in the 'Brixol F1' variety with the diameter of $20-30 \mathrm{~mm}$, which was likely to have a positive effect on crop production. Valšíková (1987) reported the colour of the stem as dark green, covered with small hairs, which was confirmed in the results of our varieties. Both varieties had dense and mighty foliage. The leaf type was normal, slightly curly and covered with truncated trichomes (Zimolka, 2008). The colour of the leaves was classified as green.

\section{Vine}

Vine was moderately dense for both varieties. For the 'Uno Rosso F1' variety, the length of vine was up to $0.25 \mathrm{~m}$ and for 'Brixol F1' from 0.25 to $0.30 \mathrm{~m}$. The average number of flowers in vine ranged from 14 to 16 for 'Uno Rosso F1' and 17 to 19 for 'Brixol F1'.

\section{Inflorescence}

As a part of floral morphology, we observed the colour, size and frequency of the flowers. Authors Andrejiová and Kóňa (2010) claimed that flowers of the new varieties have yellow colour and have six digits. The variety 'Uno Rosso F1' had larger flowers with 6-7 tips in comparison with 'Brixol F1'. From the morphology of inflorescence we evaluated the creations of flowering, the relative length and shape of the stigma and anther. These characters were the same for both varieties. The first inflorescence is usually based on sixth to eighth sheet (Uher et al., 2016). The 'Brixol F1' variety is based on inflorescences on $8^{\text {th }}$ to $9^{\text {th }}$ leaves and 'Brixol F1' at $6^{\text {th }}-7^{\text {th }}$ leaves. The length of stigmas and anther was in both varieties on the same level.

Fruit

We followed the surface of tomato fruits, the basic colour of the immature fruits, the size of fruits and the colour of the skin. Rosembergerová (2013) stated that the weight of 'Uno Rosso F1' variety fruit is about 55-60 g and at 'Brixol

Table 5 Multiple Range Tests for Number of fruits per plant by varieties

\begin{tabular}{|c|c|c|c|c|c|c|}
\hline Varieties & Count & LS Mean & LS Sigma & \multicolumn{3}{|c|}{ Homogeneous Groups } \\
\hline Uno Rosso & 8 & 87.25 & 4.23029 & $x$ & & \\
\hline Brixol & 8 & 104.125 & 4.23029 & & $\mathrm{x}$ & \\
\hline Years & Count & LS Mean & LS Sigma & \multicolumn{3}{|c|}{ Homogeneous Groups } \\
\hline 2016 & 8 & 85.5 & 4.23029 & $x$ & & \\
\hline 2017 & 8 & 105.875 & 4.23029 & & $x$ & \\
\hline Variants & Count & LS Mean & LS Sigma & \multicolumn{3}{|c|}{ Homogeneous Groups } \\
\hline 1.v & 4 & 60.75 & 5.98253 & $x$ & & \\
\hline 2. V & 4 & 91.25 & 5.98253 & & $x$ & \\
\hline 4. $V$ & 4 & 113.5 & 5.98253 & & & $x$ \\
\hline 3. $\mathrm{V}$ & 4 & 117.25 & 5.98253 & & & $x$ \\
\hline
\end{tabular}

Method: $95.0 \%$ LSD 
F1' variety it is about 68-70 g. The weight was also affected by fertilization in variants of our experiments. The highest weight of fruits was found in the $4^{\text {th }}$ variant, which was fertilized in both liquid and loose form of the Rokosan fertilizer. The shape of the fruits from the side view of 'Uno Rosso F1' was slightly elongated. From the top view, the shape was rounded triangular. The 'Brixol F1' variety has a rather spherical shape and an irregular shape from the top view. Both varieties have smooth surface of fruits. The top of the fruits has the 'Uno Rosso F1' variety without the tip and the fruit has a slightly developed green ring. On the contrary, the 'Brixol F1' variety has a peak of the fruits with few pronounced spikes and the fruit has no ring. The variety 'Uno Rosso F1' has a large stem hole (5-10 mm), red flesh, and berries have four chambers. The 'Brixol F1' variety has a shallower stem hole, up to $5 \mathrm{~mm}$, the red flesh and the fruits have from 5 to 10 chambers.

\section{Phenological features}

Sowing the seeds was realized on March 14, 2016. Both varieties belong to field tomatoes, which meet the requirements for industrial processing, reported by Mareček et al. (2001). After five days, the seeds germinated. Eight days after sowing, on March 22, 2016, the first primary leaves began to form. On March 30, 2016, seedlings were transplanted. The first right leaves were created 25 days after sowing. Hypocotyl colour was dark green, anthocyanin discoloration occurred. After 72 days from sowing, on May 25,2016 , we planted the seedlings on the outdoor site. The seedlings height was around $0.30-0.35 \mathrm{~m}$. 'Brixol F1' variety began to blossom first, 4 days after planting, and 'Uno Rosso F1' variety after 8 days from planting (June 2, 2016). The date of the first fruit creation for the 'Uno Rosso F1' variety was June 20, 2016 (26 days from planting), for 'Brixol F1' it was June 14, 2016 (20 days from planting). In the 'Brixol F1' variety, the first fruits began to mature 53 days after planting and in 'Uno Rosso F1' 56 days after planting. The harvests were carried out manually. The first harvest took place on August 8, 2016 (75 days from planting), the second one on August 18, 2016 (85 days from planting) and the third one on August 30, 2016 (97 days from planting).

\section{Conclusions}

As for the years of experiments, the more favourable one for the cultivation of field tomatoes was the year 2017. In the 'Uno Rosso F1' variety, yield variations ranged from 2.19 to $8.96 \mathrm{~kg}$ per plant. The 'Brixol F1' variety showed yield from 3.19 to $9.24 \mathrm{~kg}$ per plant. The yield and the number of tomato fruits were best suited by variety with the Rokohumin Z fertilizer. It is also evidenced by the highest total yield in the variant 3 out of the three harvests in 2016 and in 2017. The variant fertilized only with the bulk fertilizer Rokosan P took third place in the crop level. In terms of yields and number of fruits, the second place was taken by the variety with combined fertilization of bulk (Rokosan P) and liquid (Rokohumin Z) fertilizers. Out of the two varieties in question, 'Brixol F1' was more productive in both years and in all variants. Even when evaluating the number of fruits per plant, the 'Brixol F1' was more successful in both years.

\section{References}

ANDREJIOVÁ, A. - KÓŇA, J. 2010. Návody na cvičenia zo zeleninárstva. Nitra : SPU, 2010, 109 s. ISBN 978-80-552-0334-8.

FAOSTAT. 2014. Free database Food and Agriculture Organization of United Nations. Cit. 2017-11-03, available from: http://www.fao. org/faostat/en/\#data/QC

FLOWERDEW, B. 2011. Sázení, zalévání a hnojení. 1. vyd., Praha : Metafora, 2011, 114 s. ISBN 978-80-7359-273-8.

HELYES, L. - LUGAS, A. - PÉK, Z. 2012. Effect of irrigation on processing tomato yield and antioxidant components. In Turk J Agric For, vol. 36, 2012, pp. 702-709. doi:10.3906/tar-1107-9.

HEUVELINK, E. 2005. Tomatoes. CABI, 2005. ISBN 9780851993966.

HLUŠEK, J. 2004. Základy výživy a hnojení zeleniny a ovocných kultur. 2. vyd., Praha: Ústav zem. a potravinár. informácí, 2004, 57 s. ISBN 80-7271-147-4.

IPGRI. 1996. Descriptors for Tomato (Lycopersicon spp.). Rome, Italy : International Plant Genetic Resources Institute, 1996, 44. p. ISBN 92-9043-294-2.

LOŽEK, O. et al. 2000. Hnojenie záhradných plodín. 1. vyd., Nitra : SPU, 2000. 116 s. ISBN 80-7137-735-X.

MAREČEK, F. et al. 2001. Zahradnický slovník naučný 5 (R - Ž). Praha : Ústav zemědělských a potravinářských informací, 2001, 687 s. ISBN 80-7271-075-3.

MERAVÁ, E. a i. 2017. Zelenina. In Situačná a výhladová správa k 31. 12. 2016, roč. 22, 2017, 54 s. SSN 1338-8010.

OROSCO. 2013. Vetőmag katalógus. Orosháza : Orosco KFT, 2013, 23 p. PATANE, C. - COSENTINO, S.I. 2009. Effects of soil water deficit on yield and quality of processing tomato under a Mediterranean climate. Available from: https://doi.org/10.1016/j.agwat.2009.08.021

https://doi.org/10.1016/j.agwat.2009.08.021

ROKOSAN. 2017. Hnojivá Rokosan. [online]. [cit. 2017-02-14]. Available from: http://www.rokosan.sk/sk/rokosan_charakteristika.php

ROZBORILOVÁ, E. a i. 2017. Definitívne údaje o úrode pol'nohospodárskych plodín a zeleniny v SR za rok 2016. Štatistický úrad SR, 2017. ISBN 978-80-8121-579-7.

ROSEMBERGEROVÁ, J. 2013. Rajčiaky: Návod na pestovanie od A po Z. Cit. 2017-01-22, available from: http://www.pluska.sk/ izahradkar/uzitkova-zahrada/ovocie-zelenina/04/rajciaky-navodpestovanie-od-po-z.html

RUBATZKY, V. E. - YAMAGUCHI, M. 1997. World Vegetables Principles, Production and Nutritive Values. New York : Springer, 1997. ISBN 978-1-4615-6015-9.

TAIWO, L. B. - ADEDIRAN, J. A. - SONUBI, O. A. 2008. Yield and Quality of Tomato Grown with Organic and Synthetic Fertilizers. In International Journal of Vegetable Science, 2008, pp. 5-19. Published online: 22 Sep 2008, available from: http://doi. org/10.1300/J512v13n02_02

TIGIST, A. - WORKNEH, S. - WOLDETSADIK, K. 2012. Effects of variety on yield, physical properties and storability of tomato under ambient conditions. In African Journal of Agricultural Research, vol. 7, 2012, no. 45, pp. 6005-6015. http://www.academicjournals.org/ AJAR, DOI: 10.5897/AJAR11.1215

UHER, A. a i. 2016. Polné a záhradné plodiny. Nitra : SPU, 2016. ISBN 978-80-552-1474-0.

VALŠíKOVÁ, M. a i. 1987. Papriky, rajčiaky a baklažány. Bratislava : Príroda, 1987.

WANG, X. - XING, Y. 2017. Evaluation of the effects of irrigation and fertilization on tomato fruit yield and quality: a principal component analysis. In Scientific Reports, vol. 7, 2017, article no. 350. Doi:10.1038/s41598-017-00373-8.

ZIMOLKA, J. 2008. Speciální produkce - rostlinná výroba 2. Brno : MZLU, 2008. 247 s. ISBN 978-80-7375-230-9. 